\title{
EUTROPHICATION AS A PRIORITY ISSUE OF WATER QUALITY IN SMALL RETENTION RESERVOIRS
}

\author{
Anna Siemieniuk', Joanna Szczykowska', Józefa Wiater ${ }^{1}$ \\ 1 Faculty of Civil and Environmental Technology, Bialystok University of Technology, Wiejska 45E Str., 15-351 \\ Białystok, Poland, e-mail: a.siemieniuk@pb.edu.pl
}

Received: 2016.03.16 Accepted: 2016.06.01 Published: 2016.07.01

\begin{abstract}
The study aimed at comparing changes in the trophic status of waters in two small retention reservoirs "Otapy-Kiersnówek" and "Jasionówka", located in the Podlasie region, which have a similar way of management and the similarity of catchments, using the TSI trophy indicators. The obtained results show that total phosphorus is the limiting factor in both reservoirs. Analyzing the average annual value of TSI in the tested waters, it was found that both reservoirs can be classified as hypertrophic. Trophic state of the tested waters is strictly dependent on the processes taking place in their vicinity. The reservoirs revealed a clear effect of a surface runoff on water quality. Factors that favor the poor quality of water in both reservoirs are unfavorable morphometric conditions of reservoirs due to their small depth, which allows continuous mixing and strong heating of water in spring and summer. Additional causes can include an open space around the reservoirs and the lack of high vegetation that would shield the edges against the wind, which facilitates often mixing of waters to the bottom and resuspension of bottom sediments, which in turn increases the concentration of phosphorus in water.
\end{abstract}

Keywords: eutrophication, small retention reservoirs, biogenic compounds, trophic state index TSI

\section{INTRODUCTION}

The increase in fertility of reservoirs is part of a natural process, which is sometimes referred to as "water aging" and is a manifestation of natural evolution of all water bodies. However, accelerated eutrophication of many reservoirs is the result of wider understood human activity. Changing in the status and quality of surface water is determined not only by the supply of nutrients from external sources, but also processes that take place within aquatic ecosystems. The rate of eutrophic processes, which are a function of the amount of biogenic compounds accumulated in aquatic ecosystems, increases there. In extremely productive reservoirs, algal blooms affecting the reduction of usable water are the consequence of eutrophication, and therefore, to understand the nature of the reservoir's trophy is a very important element. These activities are aimed at understanding the functioning and opportunities of the proper management of each reservoir.

To assess the trophic status of retention reservoirs, the Carlson's as well as Kratzer and Brezonik's Trophic State Index (TSI) can be applied [Carlson 1977, Kratzer, Brezonic 1981], which is based on measurements of chlorophyll "a", total phosphorus, total nitrogen concentrations, and water transparency measured using Secchi disk. These indices - TSI(Chl), TSI(P), TSI(N), TSI(SD) - are convenient to apply, because they consist in measurements always carried out in the reservoir and they are also based on causes (nitrogen and phosphorus contents) and effects (development of phytoplankton measured by chlorophyll concentration), as well as symptoms of these effects, i.e. water transparency. 
The study aimed at comparing changes in the trophic status of waters with the use of trophic indicators TSI in two small retention reservoirs located in Podlasie region that have a similar way of management and the similarity of catchments.

\section{STUDY AREA AND METHODOLOGY}

The study was carried out on the basis of water samples from two small retention reservoirs "Otapy-Kiersnówek" (municipality Brańsk) and "Jasionówka" (municipality Jasionówka), located in Podlasie region. The choice of these reservoirs was suggested by the way of management and similarity of catchments. Agricultural land constituting $78.1 \%$ and $15.6 \%$ forests dominated in the catchment area of the analyzed reservoir in municipality Bransk. In the municipality Jasionówka, arable land represents $81 \%$ while forests $13 \%$ of the area. Mineral soils predominate in catchment area of all reservoirs.

Reservoir Otapy-Kiersnówek was established in the municipality Brańsk on the river Nurzec in 2008. Its surface area is 4.8 ha, the average depth $1.6 \mathrm{~m}$, and the retention capacity 62 thousand $\mathrm{m}^{3}$. The land occupied by an investment accounted for pastures of $\mathrm{V}$ class and small areas of agricultural land of III and IV classes. In the Nurzec river valley, mainly layers of silt deposited by water during the floods of the river and occur, as well as peat and muck-peat soils on a small area. Bransk is a rural municipality, which includes 43 village councils. The village is dominated by agricultural production, including cultivation of cereals and breeding of cattle and swine.

Jasionówka reservoir was created in 2001 in the waters of R-71/2 ditch, which is supplied by waters of Brzozówka river, which is a left tributary of the Biebrza river. Its area is 2.03 ha, the average depth $2.3 \mathrm{~m}$, and the retention capacity 41.6 thousand $\mathrm{m}^{3}$. The bottom of the reservoir is not very diverse and on most surfaces there are pieces of clay and sand-gravel formations. The reservoir is supplied by waters of a drainage ditch R-71/2 and the drainage network. Melioration works were made in the 60 's for the former PGR Jasionówka. The catchment is dominated by boulder clay, boulder sand, as well as sander sands and gravels. Direct catchment area is deforested with predominantly agricultural land use and complexes of permanent grassland (meadows and pastures) that are extensively used.
Water retention for irrigation of agricultural land, mainly pastures, is the primary purpose of these facilities construction. Another purpose is to reduce the flood risk. However, the studied reservoirs are used mainly for the recreation and sport purpose as well as for extensive fish farming.

The study was carried out using samples of surface water from the reservoirs, which were collected regularly every month in the period from March 2007 to February 2014, from three research positions. Selection and placement of measurement and control points in longitudinal section of the reservoirs was a result of the need to capture changes in studied physicochemical properties of water. The first point was located within the tributaries, the second in their central parts, and the third at the mouths of the reservoirs. Following items were determined in collected water samples: total nitrogen and total phosphorus concentrations in accordance with obligatory methods [Hermanowicz et al. 1999]; moreover, chlorophyll "a" concentration according to standard PN-ISO10260:2002 by means of spectrophotometric method in a range of $30 \div 80 \mu \mathrm{g} / \mathrm{dm}^{3}$. In order to assess the trophic status of such small retention reservoirs, it seemed to be unimportant to determine water transparency. It was observed during studies that after heavy rainfalls, inflowing waters supplied considerable amounts of suspensions making retention water turbid and affecting the deterioration of their transparency that was not associated with phytoplankton development. Therefore, this element of TSI(SD) was skipped during the assessment of water trophic status [Szczykowska, Siemieniuk, Wiater 2015].

The values of the trophic state indices according to Carlson are as follows: TSI $<40$ - oligotrophy, 40-50 mesotrophy, 50-70 eutrophy, $>70$ hypertrophy [Carlson 1977]. Evaluation of the eutrophication degree is made on a base of average annual values of biogenic indicators for flowing waters [Dz.U. No 241, 2002].

According to the Water Framework Directive, water in dam reservoirs is treated as water from strongly transformed, modified and artificial sections of uniform flowing water bodies. In the assessment of water quality, the reference is made to the Regulation of the Minister of Environment of 22 October 2014 on the classification of the status of uniform surface water sections and environ- 
mental quality standards for the priority substances (Dz. U. 2014 r., pos. 1482 with amendments).

\section{RESULTS AND DISCUSSION}

Concentrations of total nitrogen and total phosphorus in water in the subsequent years of research were characterized by remarkable variability. Regardless of the study year, seasonal changes in these indicators of water quality were recorded. The lowest concentrations of both total nitrogen and total phosphorus were observed in summer and autumn, while the highest in winter and spring (Table 1). Seasonal differences in nutrients concentrations in water of the reservoirs are connected with plant's vegetation, which was earlier proved by Koc et al. (2008). At the same time, gradual average annual increase in the concentration of nutrients was observed in time (Table 2). Factor that caused high concentrations of both nitrogen and phosphorus over the years of research could be probably bottom sediment covering bottom of the reservoirs, which penetrated the reservoir waters in a form of humic substances along with the waters of rivers supplying water to particular reservoirs from surrounding catchments, which are of agricultural-forest character.
The content of chlorophyll "a" in waters of all studied reservoirs, regardless of the research year, was also subject to seasonal changes. The increase in the concentration of chlorophyll "a" was observed in spring, summer, and in fall it slightly decreased to almost complete disappearance in winter. Same as in the case of total nitrogen and total phosphorus, a gradual increase in the average annual contaminants expressed in the amount of chlorophyll "a" in all discussed reservoirs, was observed in the course of the study period (Table 1, 2).

The studies revealed that total phosphorus was the factor that limited water quality in Jasionówka reservoir. Values of TSI(TP) were almost always recorded at the level higher than 100, and only in 2011/2012 they amounted to 86.9. According to literature data [Galvez-Cloutier, Sanchez 2007, Smith, Tilman, Nekola 1999], in majority of lakes and dam reservoirs, usually phosphorus is the element limiting the primary production. Values of TSI(TN) were lower (87.88-93.72), however, classified water to eutrophic ones. TSI(Chl) was much lower (52.52-60.15), although water in the reservoir can be classified as eutrophic. The annual trophy level makes the Jasionówka reservoir be classified as hypertrophic (Figure 1).

High load of Otapy-Kiersnówek reservoir water with biogenic compounds classified that the

Table 1. Minimum, maximum, and average values of studied indicators in individual seasons within the study period in analyzed reservoirs

\begin{tabular}{|l|c|c|c|c|c|}
\hline \multicolumn{2}{|c|}{ Reservoir/season } & Spring & Summer & Autumn & Winter \\
\cline { 2 - 6 } & & min - max/ average & min - max/ average & min - max/ average & min - max/ average \\
\hline \multirow{3}{*}{$\begin{array}{l}\text { Otapy - } \\
\text { Kiersnówek }\end{array}$} & $\mathrm{N}_{\mathrm{og}}$ & $13,81-19,55 / 17,72$ & $2,82-5,76 / 6,09$ & $8,18-9,25 / 8,65$ & $16,01-16,67 / 16,36$ \\
\cline { 2 - 6 } & $\mathrm{P}_{\mathrm{og}}$ & $0,935-2,669 / 2,029$ & $0,385-1,099 / 0,866$ & $0,749-0,981 / 0,848$ & $1,524-2,778 / 2,230$ \\
\cline { 2 - 6 } & $\mathrm{Chl}_{\mathrm{a}}$ & $17,82-31,58 / 25,24$ & $20,02-38,12 / 29,05$ & $13,90-25,53 / 19,82$ & $3,05-4,37 / 3,58$ \\
\hline \multirow{3}{*}{ Jasionówka } & $\mathrm{N}_{\mathrm{og}}$ & $12,53-22,87 / 19,15$ & $2,48-8,62 / 5,87$ & $8,68-10,09 / 9,08$ & $16,74-20,62 / 18,50$ \\
\cline { 2 - 6 } & $\mathrm{P}_{\mathrm{og}}$ & $0,439-2,827 / 1,642$ & $0,065-1,865 / 0,797$ & $0,142-1,297 / 0,82$ & $0,593-3,171 / 2,117$ \\
\cline { 2 - 6 } & $\mathrm{Chl}$ & $17,82-28,56 / 23,69$ & $9,69-29,13 / 19,89$ & $6,9-20,52 / 14,12$ & $3,05-4,28 / 3,56$ \\
\hline
\end{tabular}

Table 2. Minimum, maximum, and average values of studied indicators of water samples from analyzed reservoirs in individual years of study

\begin{tabular}{|l|c|c|c|c|c|}
\hline \multicolumn{2}{|c|}{$\begin{array}{c}\text { Years of examinations/ } \\
\text { reservoir }\end{array}$} & $2007 / 2008$ & $2009 / 2010$ & $2011 / 2012$ & $2013 / 2014$ \\
\cline { 2 - 6 } & $\mathrm{N}_{\mathrm{og}}$ & $1,94-21,48 / 10,34$ & $3,76-22,54 / 12,21$ & $4,51-22,56 / 12,33$ & $4,23-23,75 / 12,54$ \\
\hline \multirow{3}{*}{$\begin{array}{l}\text { Otapy - } \\
\text { Kiersnówek }\end{array}$} & $\mathrm{P}_{\mathrm{og}}$ & $0,287-1,604 / 0,91$ & $0,594-2,745 / 1,298$ & $0,698-3,568 / 1,818$ & $0,624-3,655 / 1,85$ \\
\cline { 2 - 6 } & $\mathrm{Chl}_{\mathrm{a}}$ & $2,91-21,24 / 13,7$ & $2,93-25,91 / 17,2$ & $3,24-39,84 / 21,89$ & $3,58-38,61 / 24,9$ \\
\hline \multirow{3}{*}{ Jasionówka } & $\mathrm{N}_{\mathrm{og}}$ & $1,56-20,21 / 10,14$ & $4,21-22,62 / 12,45$ & $5,51-24,95 / 14,81$ & $5,83-24,79 / 15,2$ \\
\cline { 2 - 6 } & $\mathrm{P}_{\mathrm{og}}$ & $0,422-1,704 / 1,02$ & $0,678-3,481 / 1,78$ & $0,034-0,989 / 0,31$ & $0,924-3,655 / 2,27$ \\
\cline { 2 - 6 } & $\mathrm{Ch}_{\mathrm{a}}$ & $2,91-20,82 / 9,37$ & $2,93-22,83 / 13,67$ & $3,23-34,74 / 17,7$ & $3,54-31,61 / 20,52$ \\
\hline
\end{tabular}


body of water to hypertrophic, whilst the TSI(TP) was at higher level than TSI(TN). Throughout the whole period of study, the TSI(Chl) was within the range of 56.22-62.17, qualifying the reservoir to eutrophic ones. The annual trophic level categorizes Otapy-Kiersnówek reservoir to hypertrophic (Figure 2).

Analysis of the average annual values of TSI(TN) in the studied reservoirs revealed that the indicator increased from year to year by $6.23 \%$ in Jasionówka and by $3.06 \%$ in OtapyKiersnówek reservoir in relation to the first years of the research. The same situation was recorded for TSI(TP); this indicator increased by $10.03 \%$ in Jasionówka and by $9.05 \%$ in OtapyKiersnówek reservoir. The highest percentage increase referred to TSI(Chl) - by $12.69 \%$ in Jasionówka and by $9.57 \%$ in Otapy. Annual average trophy level (TSIogólny) within analyzed period of study increased by $9.3 \%$ in the case of Jasionówka reservoir and by $7.12 \%$ in Otapy-Kiersnówek reservoir.

Undoubtedly, the trophic state of the tested waters is strictly dependent on the processes taking place on their vicinity. The most loaded biogens are waters flowing through ditches, mainly the drainage network, in agricultural areas. These small retention reservoirs are located in catchments, where in most cases light soils dominate. Load of biogens flowing with drainage water out of light soils is several times higher than that flowing out of heavy soils [Koc et al. 2009, Rafałowska 2008]. Reservoirs that store water with high levels of trophy are characterized by cyanobacterial blooms in summer and it is certainly favored by their small depth. The development of agricultural anthropogenic pressure increases the susceptibility of water bodies on the fertilization process. Gradual transformation of the catchment leads to changes, which is reflected by the surface runoff, whereby the amount of impurities entering the reservoirs increases and contributes to the growth of degradative processes in the water reservoirs. The specificity of the chemical composition of waters in agricultural and forest lands is dependent on geochemical background of a catchment and the economic impact of a man. In forest areas, where these impacts are negligible, the geochemical background and phytocoenosis prevails, while in rural areas, the geochemical background is superimposed with anthropogenic

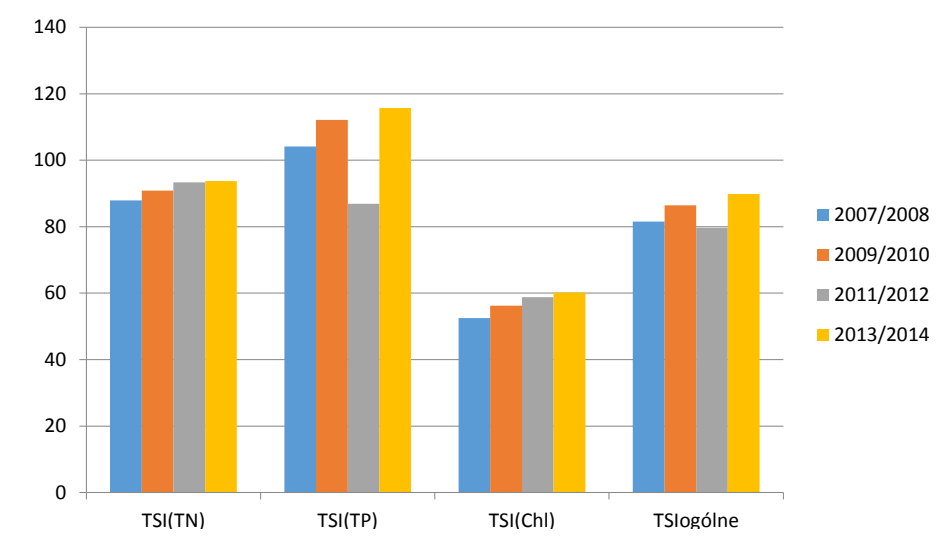

Figure 1. Annual level of TSI trophy of Jasionówka reservoir in individual years of study

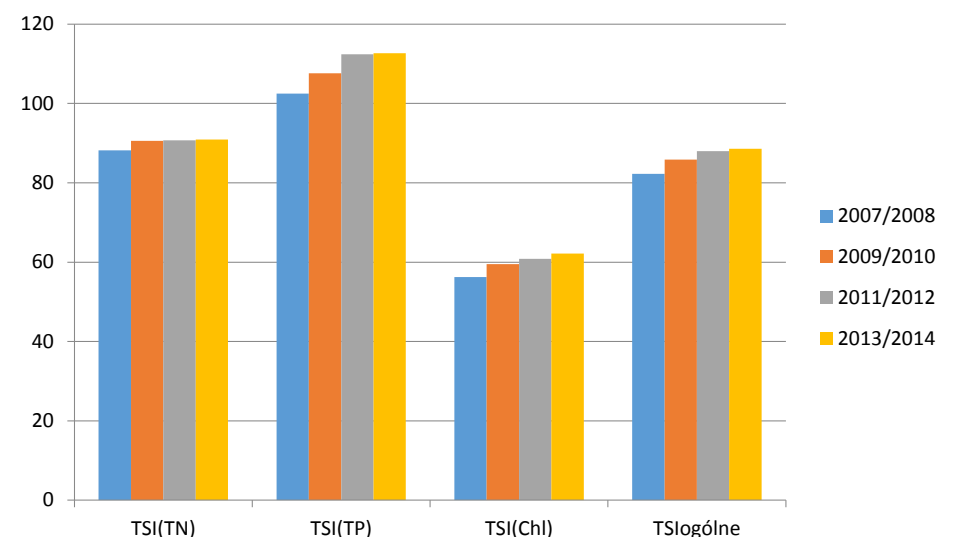

Figure 2. Annual level of TSI trophy of Otapy-Kiersnówek reservoir in individual years of study 
impact [Borowiec, Pieńkowski 1993]. Negative impact on the retained water may also be associated with the extensive use of reservoirs for fish farming. Excessive use of plant-origin baits during recreational angling increases the load of waters with nutrients. An important role influencing the migration of nutrients is played by sorption properties of soils resulting in their temporary stopping and removing from the tournament. After soil saturation with phosphorus, increase in the phosphate leaching occurs due to their release from both mineral and organic bindings. According to the research, even after giving up the fertilization and as a result of different reactions retarding migration of phosphates, their elevated concentrations to be expected for many years [Hallberg 1989]. The study clearly indicates the gradual degradation of water quality in analyzed reservoirs through the growth of trophy indices TSI.

Factors that contribute to the deterioration of water quality in small retention reservoirs "OtapyKiersnówek" and "Jasionówka" are unfavorable morphometric conditions of the reservoirs themselves due to a small depth, which allows continuous mixing of water and strong heating of water in spring and summer. Additional causes may be open space around the reservoirs and the lack of high vegetation, which would shield the edges against wind, which facilitates frequent mixing of water to the bottom and resuspension of bottom sediments affecting the increase in the concentration of phosphorus in water [Kristensen, Sondergaard, Jeppesen 1992].

\section{CONCLUSIONS}

1. The studies clearly show that eutrophication is the most important cause of the water quality deterioration of small retention in Podlasie region.

2. Total phosphorus was the factor limiting the water quality in both reservoirs.

3. The average annual values of the TSI index qualify the studied reservoirs as hypertrophic.

4. Trophic state of studied waters is strictly dependent on the processes taking place in their vicinity.

5. In shallow retention reservoirs, frequent mixing of waters to the bottom and simultaneous resuspension of bottom sediments, significantly impacts on the increase in concentration of phosphorus in water.

\section{REFERENCES}

1. Carlson R.E. 1977. A tropic state index for lakes. Limnology and Oceanography, 22(2).

2. Kratzer C.R., Brezonic P.L. 1981. A Carlson-type tropic state index for nitrogen in Florida Lakes. Water Research Bull, vol. 17.

3. Szczykowska J., Siemieniuk A., Wiater J. 2015. Agricultural pollution and water quality in small retention reservoir in Korycin, Journal of Ecological Engineering, 16(1), 141-146.

4. Hermanowicz W. et al. 1999. Fizyczno-chemiczne badanie wody i ścieków. Wydawnictwo Arkady, Warszawa 1999.

5. Rozporządzenie Ministra Środowiska z dnia 23 grudnia 2002 r. w sprawie kryteriów wyznaczania wód wrażliwych na zanieczyszczenia związkami azotu ze źródeł rolniczych. Dz. U. 2002 r. Nr 241 poz. 2093.

6. Galvez-Cloutier R., Sanchez M. 2007. Trophic Status Evaluation for 154 Lakes in Quebec, Canada: Monitoring and Recommendations. Water Qual. Res. J. Canada, 42(4), 252-268.

7. Smith V.H., Tilman G.D., Nekola J.C. 1999.Eutrophication: impacts of excess nutrient inputs on freshwater, Marine, and terrestrial ecosystems. Environmental Pollution, vol. 100, 179-196.

8. Koc J., Koc-Jurczyk J., Solarski K. 2009. Wielkość i dynamika odpływu azotu z wodami z obszarów rolniczych. Zeszyty Naukowe Polskie Towarzystwo Gleboznawcze, Warszawa, 121-128.

9. Rafałowska M. 2008. Ocena zawartości azotanów w wodach powierzchniowych obszaru szczególnie zagrożonego zanieczyszczeniami ze źródeł rolniczych. Proceedings of EC Opole 2(2), 473-478.

10. Borowiec S., Pieńkowski P. 1993. Oddziaływanie geochemiczne i antropogeniczne na chemizm wód obszarów rolniczo-leśnych Pomorza zachodniego. Geoekosystem obszarów nizinnych., Ossolineum, Wrocław, 19-23.

11. Hallberg G.R. 1989. Nitrate in ground water in United States, Nitrogen management and ground water protection. R.F. Follett (Ed.). Elsevier, Amsterdam, 35-74.

12. Kristensen P., Sondergaard M., Jeppesen E. 1992. Resuspension in a shallow eutrophic lake. Hydrobiologia, 228, 101-109. 